\title{
Internalization of Pancasila Values in the Tradition of the Serang Party
}

\author{
Jennyta Caturiasari ${ }^{1, *}$ Srie Mulyani ${ }^{2}$ Nonik Mahdarani ${ }^{3}$
}

\author{
${ }^{1,2,3}$ Universitas Pendidikan Indonesia, Bandung, Indonesia \\ Corresponding author.Email:.jennytacs@upi.edu
}

\begin{abstract}
Pancasila as the ideology of the Indonesian state is a set of values that have been crystallized into a nation's way of life. The issue of culture and national character is now in the public's spotlight. The traditional ceremony of the Serang party is one of the regional cultures that is still applied every year by the people of Serang village. In the implementation of the traditional ceremony of the Serang Party, there are values that reflect the concepts, principles and values contained in Pancasila as national identity and form the identity of citizens. The method used in this study is a qualitative approach with ethnographic study methods used to collect data and analyse data in this study. The results show that, in traditional ceremonies there is an internalization of Pancasila values including 1) the concept in the universe that there is no independent phenomenon, independent of other phenomena, and the concept of Ada which has the meaning of giving, then in it is an evidence that the ceremony The traditional attack party has a concept in Pancasila 2) the concept of gotong royong and kinship, describing the existence of cooperation by involving every member of the community involved according to their respective abilities in a common goal. 3) the concept of nationality in the implementation process, during the implementation process and after the process of carrying out traditional ceremonies.
\end{abstract}

Keywords: Internalization, Pancasila values, local wisdom.

\section{INTRODUCTION}

Activity is a form of patterned human culture in the community, which can be interpreted as a social system. The social system of the community is interpreted as an attitude of interacting with each other, in accordance with the habits carried out with the prevailing customary patterns of behavior. Art is one element of culture that cannot be separated from aspects of human life. The unitary state of the Republic of Indonesia is one of many countries that have various ethnic groups, and each ethnic group has a regional culture that contains noble cultural values.

Cultural heritage is defined as a product or result of physical culture from different traditions and spiritual achievements in the form of values from the past which are the main elements in the identity of a group or nation [1]. So cultural heritage is the development of physical culture (tangible) and cultural values (intangible) from the past. This diversity is the capital of the wealth of the Indonesian nation, one of which is cultural heritage. As the next generation, the younger generation must participate in preserving traditional arts so that they are not eroded by foreign cultures.
With the current of globalization which can cause the erosion of national values so that children are more proud of the presence of foreign cultures that enter. It can be seen from the consumptive nature of children by using foreign products compared to the nation's own products. So the slogan 'I love made in Indonesia' is just a mere word without replacing it with real action. This is the main problem that causes the disappearance of the nation's noble values, especially in terms of culture [2]. These experiences show that the importance of understanding for generations of the nation is to continue to be able to maintain the culture that is the cultural identity of the Indonesian people. Therefore, by loving the homeland and the nation, it is hoped that it will be able to pass down the habits that have long been a national identity, by means of cultural inheritance through customs that are continuously preserved in order to foster a sense of love for Indonesian culture in particular being able to strengthen national identity in accordance with the Pancasila philosophy. In the development of local culture in each region, of course, there are significant differences in instilling a sense of love for the homeland and nation, because the local cultural arts contain very different social values. The 
ability of traditional communities to maintain their existence is a big challenge, therefore considering the awareness of noble values that need cooperation from stakeholders and the community.

\subsection{Traditional Serang party}

The traditional ceremony of the Serang party is one of the regional cultures that is still applied every year by the Serang village community, which is located in the Klangenan sub-district, Cirebon district. This greatgrandfather's visit is known as the Serang Party or traditional ceremony, which is an expression of gratitude to God Almighty for the safety and blessings in the lives of the Serang villagers for one year. In the implementation of the traditional ceremony of the Serang party, there are values that reflect the concepts, principles and values contained in the implicit Pancasila which continue to become local cultural heritage. The Serang Party is important to be held for Serang residents, in this case, it can maintain the relationship between the community, the sense of unity and brotherhood that exists and can be cultural values that can be passed down by the next generation.

In an effort to introduce regional culture through the Internalization of Pancasila Values as Strengthening National Identity in Local Wisdom, Serang Village, Klangenan District, Cirebon Regency, it is hoped that it can actualize the values of Pancasila in the implementation of the life of each individual to the wider community.

\section{LITERATURE REVIEW}

\subsection{Overview of Pancasila}

Values Historically, Pancasila, before being established as the ideology and way of life of the Indonesian people, turned out to be through long struggles and debates from Indonesian stakeholders. The debate occurred because of differences of opinion between the nationalists and Islam in the formulation of the basic state. Apart from this, at this time we believe that Pancasila as the basis of the state consists of five precepts, namely: 1) God Almighty 2) Just and civilized humanity 3) Indonesian Union 4) Democracy led by wisdom in representative deliberation 5) Social justice for all Indonesian people The precepts contained in the Pancasila have a number of values that are recognized as good and reflect the personality of the Indonesian nation. The precepts in Pancasila have a pyramidal hierarchical nature, meaning that the precepts are interconnected with one another. The first precept animates the second, third, fourth and fifth precepts. the second precept is imbued with the first precept and animates the third, fourth and fifth precepts. The third precept is inspired by the first and second precepts and animates the fourth and fifth precepts. The fourth precept is inspired by the first, second and third precepts and animates the fifth precept.
While the fifth precept is imbued with the first, second, third and fourth precepts. According to [3] Pancasila contains two values, subjective and objective. Pancasila values are said to have subjective values, meaning that Pancasila values are the result of the thoughts of the Indonesian nation throughout history, as follows: 1) Pancasila values arise from the Indonesian nation as a result of the assessment and thought of the Indonesian nation. 2) Pancasila values are a way of life, a guide to life, a guide to the life of the Indonesian nation. 3) The values of Pancasila contain seven spiritual values, namely the values of truth, justice, goodness of wisdom, ethics, aesthetics and religion whose manifestations are in accordance with the personality of the Indonesian nation.

\subsection{Local wisdom}

Local wisdom is a rule that becomes a reference for society that covers all aspects of life, in the form of rules concerning relations between human beings, for example in social interactions both between individuals and groups, which are related to hierarchies in governance and customs. , marriage rules, etiquette in everyday life. Relate to this topic [4]. A set of cultural values in an effort to appreciate and adapt to the natural surroundings, and is regulated steadily in a customary order of a society. Indigenous peoples are definitively habits that have been standardized in people's lives so that they become "social culture" that applies in a community environment.

\section{METHODS}

A qualitative approach with an ethnographic study method was used to collect data and analyze data in this study. The ethnographic method is a qualitative research procedure to describe, analyze, and interpret elements of a cultural group such as patterns of behavior, beliefs, and language that develop over time [5]. The ethnographic method provides a detailed description of the background and characteristics of a sea party ceremony in Serang, Klangenan Cirebon for the people of Serang Village, Klangenan Cirebon. The reason this research was conducted is because the people of Serang, Klangenan Cirebon still maintain the local culture of the sea party of Serang, Klangenan Cirebon until now despite the swift currents of globalization. The subjects of this research are sources who can provide information, from educational leaders in the local area, youth groups who are on the organizing committee, cultural leaders, or elders who know the history of visiting great-grandfathers/attacking parties, and the related fishing community in Klangenan Village. The experience of fishermen who have directly carried out traditional sea party activities. Sources who can provide the main information are traditional leaders who are usually appointed to be caretakers during the Serang Party because these figures know a lot about the traditional Serang party ceremony, while the supporting sources to strengthen the information are part of the community. 


\section{RESULTS AND DISCUSSION}

The implementation of research activities that have been carried out has resulted in a source of values listed in the activities of the great-grandfather's visiting traditional party. From the attack party activities, there are Pancasila values in which there are values that can be imitated. The concept in the attack party activity certainly has values that can be used and preserved in the life of the Serang community, of course, the following values are listed in the traditional activities of the Serang party:

1. Religious values / Religion, the tahlilan event is carried out as a form of gratitude to God Almighty for safety and blessings and pray for the ancestors

2. Human values, human values in this event there is compensation for orphans.

3. Social value $=$ in the preservation of the traditional customs of the Serang Party, all the series of events held can maintain ties of friendship and strengthen brotherly relations with each other because there is an interaction relationship, a sense of mutual cooperation, and concern among fellow Serang village communities.

4. Cultural Value $=$ this raid party activity is celebrated with a procession, and in the procession there is a large cone made so that the ancestors can go around enjoying the procession and then there are also events such as shadow puppet shows, plays and organ tarlings .

5. Unity Value $=$ unity value in Serang village activities can be seen when a series of Serang party events are held. The villagers attacked together to help each other and work together in the activities of the event. For example, in the tahlilan event, the Serang villagers usually give each other a cake and then in terms of financing, the Serang villagers help with funds for the Serang party activities and what is most visible is when during the procession, there are Serang village community members who carry the replica manually. together

6. The value of creativity, the value of creativity in this Serang party can be seen in the procession activities, the participation of the Serang village community to enliven this traditional event is one of them by making a replica of a good and unique replica such as birds, boats, ogo - ogo and so on.

That cultural wisdom is closely related to ethnic terms [6]. Ethnic groups are people who are bound by the awareness and identity of "cultural unity", and the language element is their trademark. So in this understanding cultural unity can lie in the habit patterns that make up the identity or characteristics of the culture.
In line with this, indigenous peoples are definitively habits that have been standardized in people's lives so that they become "social culture" that applies in a community environment [4]. A study that discusses a set of cultural values in an effort to respect and be adaptive to the natural surroundings, and is regularly arranged in a society's customary order, can be seen from the activities carried out by indigenous peoples in Cirebon district.

\section{CONCLUSION}

Ngunjung great-grandfather Serang, is an activity to express gratitude to God and as a form of respect for the great-grandchildren of Serang Village. Attack party activities have been going on for generations and are held every year. Visiting the great-grandchildren of Serang Village is also an event for friendship because many residents do not return during Eid, but with this event all gather to enliven traditions and as a forum for all village residents to be creative. Culture cannot be separated from education, because culture is the foundation or basis of education itself. the opportunity to study traditional arts so that westernization culture dominates the lifestyle of today's young generation, so that it is in accordance with the educational values of Pancasila and the nation's character which in the end the goals of national education can be achieved.

\section{REFERENCES}

[1] C Mc Conville dan G. Davison, A Heritage Handbook. St. Leonard: NSW: Allen \& Unwin, 1991.

[2] W. Wuryandi, Integrasi Nilai-Nilai Kearifan Lokal Dalam Pembelajaran Untuk Menanamkan Nasionalisme Di Sekolah. online, 2010.

[3] K. Komalasari, Pendidikan Pancasila. Surabaya: Lentera Cendekia, 2007.

[4] I. Indrawardana, "Kearifan lokal adat masyarakat Sunda dalam hubungan dengan lingkungan alam. Komunitas," vol. 4, no. 1, hal. 1-8, 2012.

[5] J. W. Creswell, Research design: qualitative, quantitative, and mixed methods approaches. London: SAGE Publications, 2009.

[6] Fajrussalam, H., \& Hasanah, A. (2018). Core Ethical Values of Character Education Based on Sundanese Culture Value. IJECA (International Journal of Education and Curriculum Application), 1(3), 15-22. 